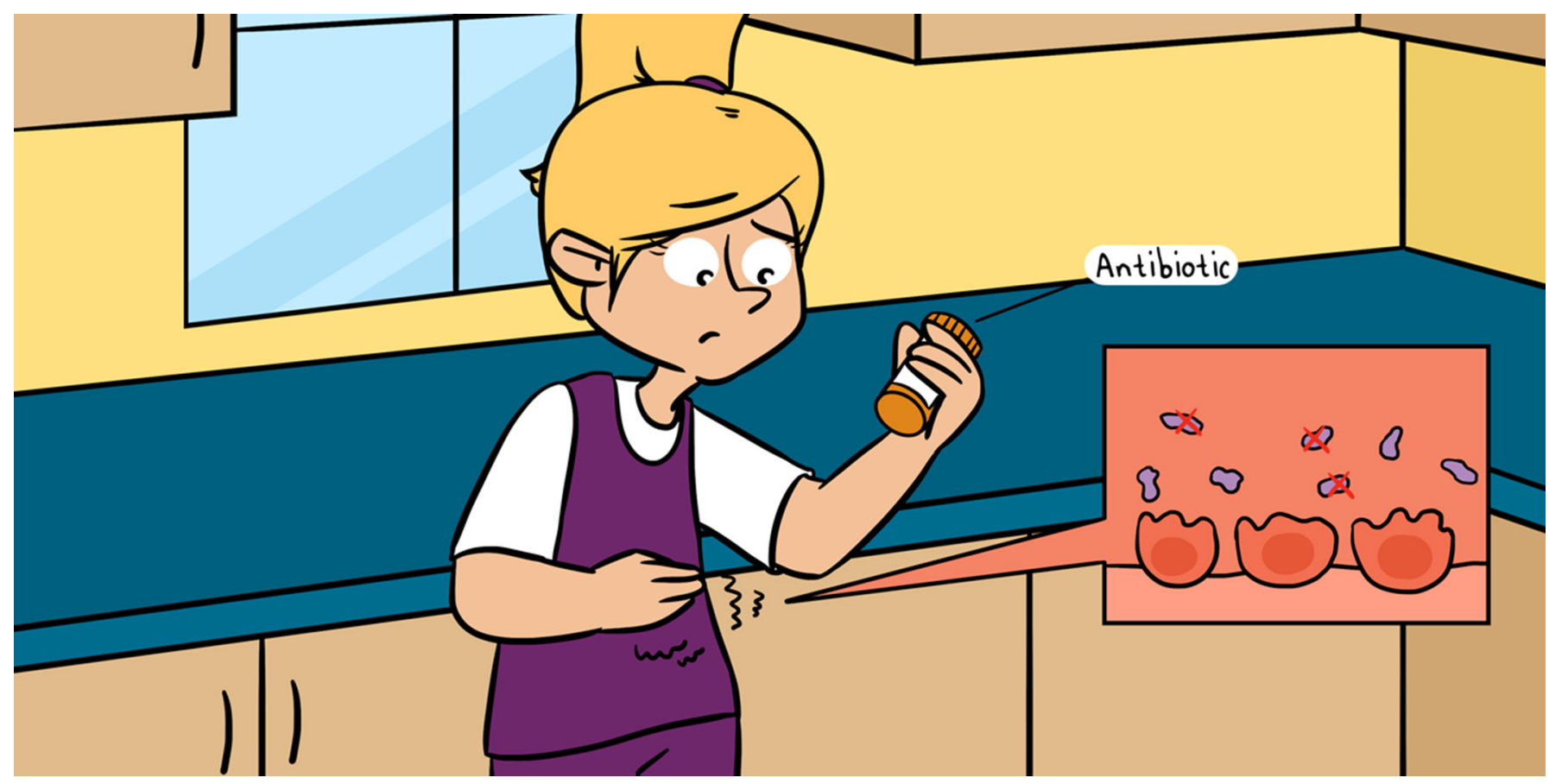

\title{
CLOSTRIDIUM DIFFICILE: BACTERIA THAT CAN INFECT PEOPLE TAKING ANTIBIOTICS
}

\section{Michel Delmée*}

Faculty of Medicine, Université Catholique de Louvain, Brussels, Belgium

\section{YOUNG REVIEWER:}

ETHAN

AGE: 15
If I ask you what antibiotics are for, you will probably say that they are used to treat infections, by killing the bacteria responsible for those infections. Well, in this article I will explain to you that there are some circumstances in which antibiotic treatment may instead cause an infection. The microbe responsible for this infection is called Clostridium difficile. I will explain which is this curious microbe, how and when it causes an infection, why antibiotics are implicated and how we can treat it ...

\section{CLOSTRIDIUM DIFFICILE AND ITS FAMILY}

Clostridium difficile belongs to a family of bacteria that are among the deadliest microbes on earth. Another member of the family, Clostridium tetani causes tetanus; Clostridium botulinum is responsible for a deadly disease called botulism; and Clostridium perfringens is the main cause of gas gangrene. All these bacteria can kill a human within a few hours! Fortunately, $C$. difficile does not kill as easily as its family members but unfortunately it is much 


\section{CLOSTRIDIUM}

A bacterial genus including pathogenic species which are anaerobic, produce toxins, and can form spores.

\section{SPORE}

A thick shell made of proteins which allows Clostridium to protect themselves against external threats.

\section{TOXINS}

Molecules secreted by bacteria that specifically target human or animal cells inducing a toxic effect. more common and has become one of the most frequent pathogens encountered in hospitals [1, 2].

All members of the Clostridium family share three properties that explain why they are so dangerous. First, they are anaerobic bacteria. This means that they cannot survive in the presence of oxygen-they can only grow where oxygen is absent. There is one important place in the body where oxygen is absent: our intestines. That is where C. difficile can be found.

Second, members of the Clostridium family can form spores. A spore is a way for these bacteria to survive every time they are threatened by the environment. Whenever the bacterial cell faces a mortal enemy, like the presence of oxygen, extreme heat, or even an antibiotic, it produces a thick shell and locks itself inside. The bacterium can remain inactive for months or even years! When the environment becomes less hostile, the spore will turn back into an active bacterium and regain the ability to multiply.

Last, bacteria of the Clostridium family produce toxins. Toxins are poisons produced by the bacteria, which can recognize and attack specific targets in the human body. In tetanus and botulism, the toxins attack the nerves and cause paralysis, while the toxins of $C$. difficile target the intestinal lining and cause diarrhea.

\section{WHAT DISEASE DOES CLOSTRIDIUM DIFFICILE CAUSE?}

C. difficile is responsible for severe diarrhea that is associated with damaged tissue in the lining of the colon, which is the final part of the large intestine. Once these bacteria begin to multiply, they secrete toxins that attack the surface of the intestines and destroy the cells [3]. This causes severe inflammation and bleeding. Since the intestinal lining is made to prevent liquids from escaping from the body, its destruction by the toxins creates leaks that spill liquid into the intestines, resulting in diarrhea (Figure 1). However, the most surprising feature of $C$. difficile is that many people contact these bacteria (by eating contaminated meat or vegetables) yet they do not suffer from diarrhea. Why?

The intestines are an interesting part of the body. There are billions of bacteria living in the intestines. If you took a gram of fecal matter and counted the number of microorganisms, you would count more than 10,000 billion cells! The number of bacteria in the intestines is higher than the number of human cells that make up the body! These intestinal bacteria belong to hundreds of different species. Most are anaerobic, which is not surprising since there is almost no oxygen in the intestines. 
Figure 1

C. difficile

secretes toxins that damage the intestinal lining. When cells of the lining die, water, and blood can leak into the intestine (represented by the dotted line), causing diarrhea.

\section{Figure 2}

The normal colonic flora is composed of billions of microorganisms (purple). When the colonic flora is healthy, C. difficile has nowhere to live and is carried through the intestines and out of the body.

\section{COLONIC FLORA}

The collection of billions of bacteria contained in the intestine.
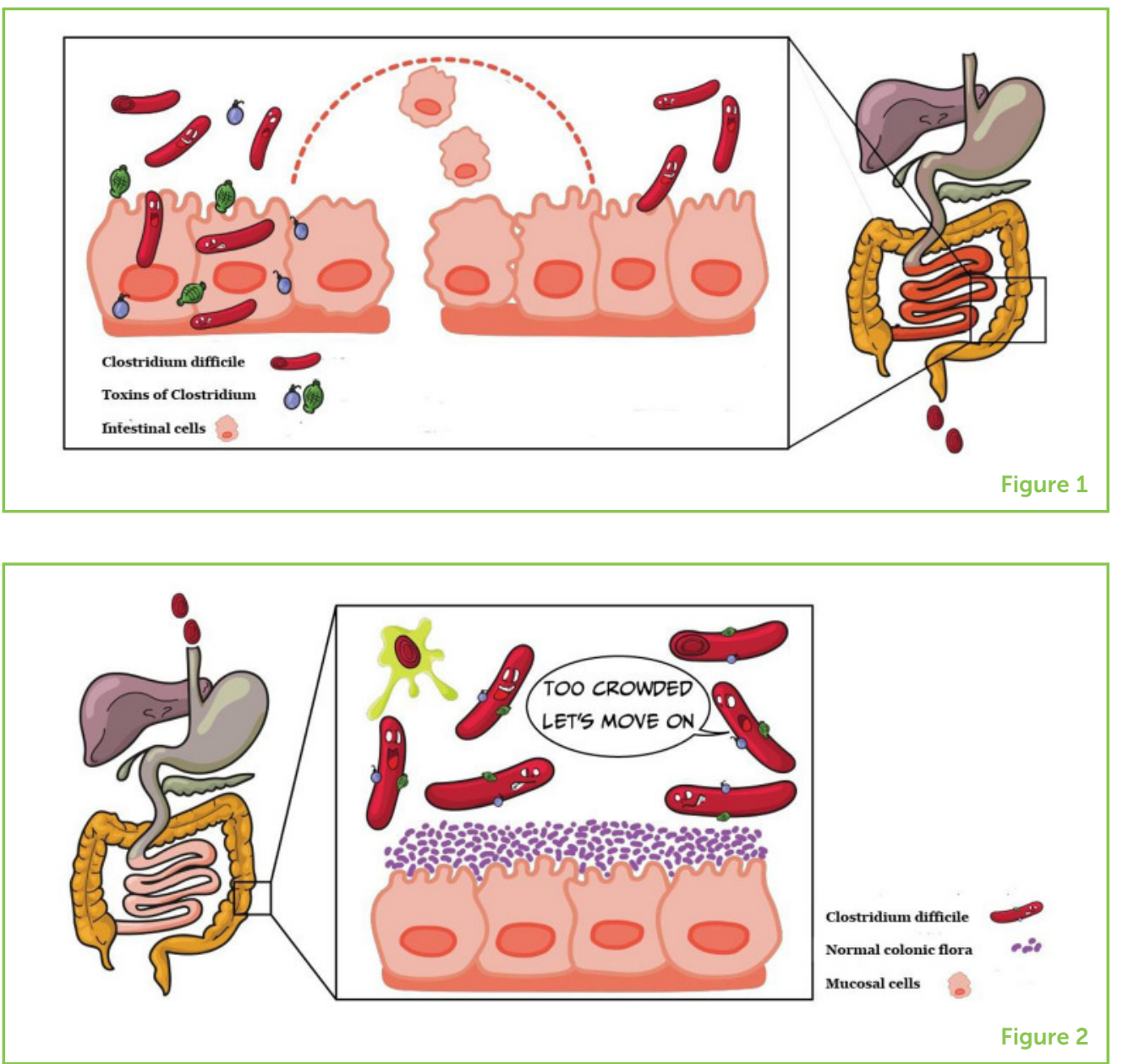

This huge population of microorganisms makes up what is called the colonic flora. The colonic flora plays many important roles. In fact, a human being could not survive without this flora. One crucial role of the colonic flora is to prevent invasion by unfriendly bacteria. In other words, when a pathogenic bacterium like $C$. difficile arrives in the intestines, it faces so many bacteria of the colonic flora that there is no place to multiply and produce its toxins, so it passes through the intestines and out of the body (Figure 2). However, there are circumstances in which the colonic flora is disturbed or partially destroyed. This happens most commonly when we take antibiotics to treat an infection.

\section{ANTIBIOTICS: BOTH GOOD AND BAD}

In the 1920s, an English microbiologist named Alexander Fleming observed a curious phenomenon: when trying to grow bacteria, he saw that a mold had developed in some of his tubes. Surprisingly, in the tubes with the mold, the bacteria did not grow and were even killed. After a lot of work, he identified a molecule that was produced by the mold, which could kill the bacteria. Since the mold was a fungus called Penicillium, he named the molecule penicillin. This was the 
Figure 3

When the colonic flora has been damaged by antibiotics, C. difficile has room to multiply. The dividing bacteria will produce toxins that damage the intestinal cells and cause diarrhea.

\section{ANTIBIOTICS}

A drug that specifically kills bacteria and is used to treat bacterial infections.

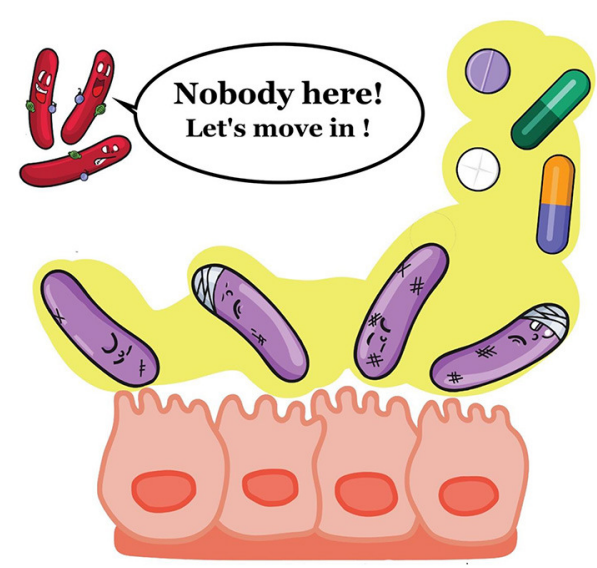

Figure 3

first antibiotic. Antibiotics are a class of drugs that can specifically kill bacteria. When a human or an animal is suffering from a bacterial infection, the first line of therapy is most often an antibiotic. Antibiotics have been "best sellers" in pharmacies all over the world for the past 80 years. This is the "good side" of antibiotics.

However, antibiotic therapy has some major drawbacks, too. Imagine you wake up tomorrow morning with a sore throat that prevents you from swallowing. You visit your doctor and he diagnoses a bacterial infection and gives you penicillin. Thanks to this wonderful drug, you will be healed 2 days later. But there is a downside! When you take an antibiotic, the drug is absorbed by your intestines into your blood. The blood passes into your throat and the antibiotic carried by the blood kills all the susceptible bacteria that it meets, including those that caused your sore throat. But the antibiotic also kills a lot of other bacteria in your body, including some of those in your intestines. Most antibiotics disturb the colonic flora. This is not usually a reason to panic. The intestinal flora will gradually return to a normal state, but it can take up to a few weeks. However, problems can occur if a person encounters a pathogenic bacteria like $C$. difficile while the intestinal flora is still recovering.

\section{CLOSTRIDIUM DIFFICILE IN HOSPITALS}

As mentioned earlier, in most cases if you encounter $C$. difficile in your meal nothing will happen ... except if you have recently taken antibiotics. Without your protective colonic flora, C. difficile can grow in your intestines, produce a lot of toxins, and cause inflammation and diarrhea (Figure 3). Fortunately, the probability of encountering C. difficile in your food is very low, so the chances of developing $C$. difficile diarrhea when you take antibiotics are relatively small. 
In hospitals, however, the situation is quite different. Hospitals are places where many patients receive antibiotics. So, outbreaks of diarrhea caused by $C$. difficile occur more frequently in hospitals. When a bedridden patient develops diarrhea, it is easy for the environment (floor, bed, tables, sheets, etc.) to become contaminated with $C$. difficile. Remember how bacteria in the Clostridium family can form spores? If $C$. difficile from the feces contaminates patient's room, these bacteria can forms spores that can persist in the hospital environment for a long time, possibly infecting the next patient occupying the room. C. difficile outbreaks can be prevented by isolating patients who have diarrhea. If patients are kept alone in their hospital rooms and a thorough daily cleaning of the whole environment is performed with bleach-containing products, spores can be eliminated and spread of $C$. difficile diarrhea can be stopped.

\section{HOW IS CLOSTRIDIUM DIFFICILE TREATED?}

Fortunately, there are a few antibiotics that act specifically against C. difficile and these can be used to treat infected people. In about $20 \%$ of the cases however, the infection may relapse, meaning that it returns after treatment. Sometimes multiple relapses may occur [4]. The main way to help people with relapsing $C$. difficile is to restore their normal colonic flora. This can be done with probiotics, for example. Probiotics are pills or capsules containing microorganisms that have been selected and grown in laboratories because they are known to grow well in the intestines and can restore normal colonic flora.

A few years ago, a doctor had a different idea for restoring the colonic flora of a patient suffering relapsing $C$. difficile diarrhea. Why not restore the damaged colonic flora with the help of the flora from a healthy person who has not taken antibiotics? A team of doctors in the Netherlands did this ... and it worked! They took $250 \mathrm{~g}$ of feces from a healthy person and diluted it in water. Then, they inserted it into the patient's intestines with a tube called a catheter. Most patients were cured! So now we know that fecal transplant is an effective technique for treating patients with relapsing $C$. difficile diarrhea.

\section{CONCLUSION}

In this article you have been introduced to a bacteria that can only cause an infection in a human who has taken antibiotics. This is very surprising since antibiotics are meant to treat infections! This bacteria is called C. difficile and, in contrast to most other bacteria, can protect itself against antibiotics by forming a spore. 
The main lesson to be learned from this article is that antibiotics are valuable medicines that should always be used wisely and only when absolutely necessary.

\section{ACKNOWLEDGMENTS}

The authors thank Susan Nasif Obeid, Anna Wozniak, and Marie Neunez who kindly drew the figures and reviewed the text.

\section{REFERENCES}

1. Kelly, C. P., and LaMont, J. T. 2008. Clostridium difficile - more difficult than ever. N. Engl. J. Med. 359:1932-40. doi: 10.1056/NEJMra0707500

2. Wilcox, M. H. 2015. Clostridium difficile infection. Infect. Dis. Clin. North Am. 29:1-178. doi: 10.1016/j.idc.2014.12.001

3. Guh, A. Y., and Kutty, P. K. 2018. Clostridioides difficile infection. Ann. Intern. Med. 169:49-64. doi: 10.7326/AITC201810020

4. Guery, B., Galperine, T., and Barbut, F. 2019. Clostridioides difficile: diagnosis and treatments. Br. Med. J. 366:14609. doi: 10.1136/bmj.14609

SUBMITTED: 27 July 2020; ACCEPTED: 12 April 2021;

PUBLISHED ONLINE: 14 May 2021.

EDITED BY: Michel Goldman, Institute for Interdisciplinary Innovation in healthcare (I3h), Belgium

CITATION: Delmée M (2021) Clostridium difficile: Bacteria That Can Infect People Taking Antibiotics. Front. Young Minds 9:587832. doi: 10.3389/frym.2021.587832

CONFLICT OF INTEREST: The author declares that the research was conducted in the absence of any commercial or financial relationships that could be construed as a potential conflict of interest.

COPYRIGHT @ 2021 Delmée. This is an open-access article distributed under the terms of the Creative Commons Attribution License (CC BY). The use, distribution or reproduction in other forums is permitted, provided the original author(s) and the copyright owner(s) are credited and that the original publication in this journal is cited, in accordance with accepted academic practice. No use, distribution or reproduction is permitted which does not comply with these terms.

\section{YOUNG REVIEWER}

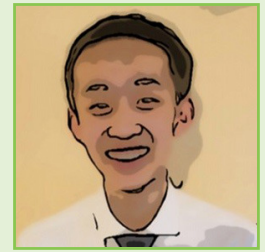

\section{ETHAN, AGE: 15}

Hi! My name is Ethan. At my regional science fair, I won Best Junior Project, Best Biology Project, Gold Medal, and a qualification to the Canada-Wide Science Fair, where I achieved a bronze medal. I have also been a finalist at the InspoScience Canada IRIC. Besides, I enjoy debating, having won the title of national champion 
and second speaker this past year, and public speaking. I am an avid writer, being published for my poems, short stories, and argumentative articles.

\section{AUTHOR}

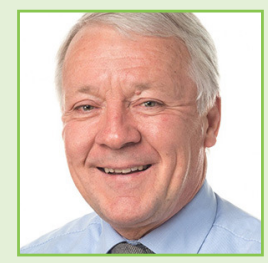

\section{MICHEL DELMÉE}

I became a doctor of medicine in 1978 and I was immediately passionate about microbiology which became my specialty. I did a doctoral thesis on this Clostridium difficile bacteria (which had just been discovered in 1978) which I presented in 1989. I became professor of microbiology at the university in 1993. I then taught microbiology to medical students while continuing doing research in a laboratory that I actually created in 1990 already. I still work there today as a professor emeritus. ${ }^{*}$ michel.delmee@uclouvain.be 